\title{
Fallopian Tube Papilloma
}

National Cancer Institute

\section{Source}

National Cancer Institute. Fallopian Tube Papilloma. NCI Thesaurus. Code C40112.

A benign epithelial neoplasm that arises from the fallopian tube. It is characterized by the presence of fibrovascular stalks lined by serous epithelial cells. 